\title{
PENGARUH GAYA BELAJAR DAN KECERDASAN MAJEMUK TERHADAP MOTIVASI BERPRESTASI MAHASISWA PESERTA MATA KULIAH PENDIDIKAN AGAMA KRISTEN ANGKATAN 2016/2017
}

\author{
Wahju Astjarjo Rini \\ Dosen Universitas Kristen Indonesia \\ Wahyuarini10862@gmail.com
}

\begin{abstract}
Abstrak
Salah satu tugas mendidik mahasiswa adalah memotivasi mahasiswa untuk menjadi lulusan terbaik, berintegritas, peduli terhadap lingkungan dan berwawasan luas. Penelitian ini dilatarbelakangi pengalaman mengajar mata kuliah Agama untuk mahasiswa angkatan 2016/2017, terdapat kecenderungan bahwa tidak semua mahasiswa mengerti gaya belajar dan kecerdasan majemuk yang dimiliki yang dapat mempengaruhi motivasi berprestasi.

Penelitian ini bertujuan untuk: (1) Untuk mengetahui pengaruh gaya belajar mahasiswa peserta mata kuliah agama Kristen terhadap kecerdasan majemuk. (2) Untuk mengetahui pengaruh gaya belajar mahasiswa peserta mata kuliah agama Kristen terhadap motivasi berprestasi. (3).Untuk mengetahui pengaruh kecerdasan majemuk mahasiswa peserta agama Kristen terdapat motivasi berprestasi..

Terdapat tiga hipotesis yang diajukan dalam penelitian ini ; (1 Diduga gaya belajar mahasiswa berpengaruh terhadap kecerdasan majemuk. (2). Diduga gaya belajar mahasiswa berpengaruh terhadap motivasi berprestasi. (3). Diduga kecerdasan majemuk mahasiswa berpengaruh terhadap motivasi berprestasi.

Metode yang digunakan dalam penelitian ini adalah kuantitatif. Dalam penelitian ini populasi dan sampel adalah mahasiswa peserta mata kuliah Agama Kristen yang diampu peneliti, sejumlah 79 responden.

Hasil penelitian menunjukkan (1) Pengaruh gaya belajar terhadap kecerdasan majemuk dengan koefisien gamma sebesar 0,556 dan T-statistic sebesar 8,983 > T tabel sebesar 1,96 pada gaya belajar terhadap kecerdasan majemuk, berarti terdapat pengaruh signifikan gaya belajar terhadap kecerdasan majemuk dengan level signifikan 0,01. (2). Pengaruh gaya belajar terhadap motivasi berprestasi mahasiswa dengan koefisien gamma sebesar 0,269 dan T-statistic sebesar 2,215 > T tabel sebesar 1,96 pada gaya belajar terhadap motivasi berprestasi mahasiswa, berarti terdapat pengaruh signifikan gaya belajar terhadap motivasi berprestasi mahasiswa dengan level signifikan 0,01. (3). Pengaruh kecerdasan majemuk, terhadap motivasi berprestasi dengan koefisien gamma sebesar 0.510 dan T-statistic sebesar $4.220>\mathrm{T}$ tabel sebesar 1,96 pada kecerdasan majemuk terhadap motivasi berprestasi mahasiswa, berarti terdapat pengaruh signifikan
\end{abstract}


kecerdasan majemuk terhadap motivasi berprestasi mahasiswa kecerdasan majemuk dengan level signifikan 0,01 .

Kata kunci: gaya belajar, kecerdasan majemuk, motivasi berprestasi.

\section{Pendahuluan}

Pendidikan merupakan cara untuk mengembangkan keterampilan, kebiasaan dan sikap dalam diri seseorang, membuat seseorang menjadi lebih baik. Menurut Peraturan Pemerintah RI Nomor 55 Tahun 2007 tentang Pendidikan Agama dan Keagamaan pada Pasal I ayat (7) Pendidikan agama diselenggarakan secara interaktif, inspiratif, menyenangkan, menantang, mendorong kreativitas dan kemandirian, serta menumbuhkan motivasi untuk hidup sukses. ${ }^{1}$ Sejalan dengan hal tersebut, maka untuk mengembangkan sikap mahasiswa melalui pengajaran yang dapat menumbuhkan motivasi.

Sebagaimana di Kejadian 1:26-2846 , manusia diciptakan segambar dengan Allah. Manusia diciptakan segambar dengan Allah, manusia menjadi makhluk yang tidak sama dengan ciptaan lain dan memampukan manusia menjalankan "kekuasaan" sebagaimana direncanakan Allah (Kejadian 1:28), dan memampukan manusia berkomunikasi dengan PenciptaNya. Manusia adalah satusatunya mahluk yang dicipta dengan memiliki rasio, kehendak bebas, moral dan hati nurani, sehingga menjadikan manusia sbg mahluk pembelajar (man of leaner). ${ }^{2}$

Dalam 2 Tim 3:16-17 Segala tulisan

\footnotetext{
${ }^{1}$ Dokumen PERATURAN PEMERINTAH REPUBLIK INDONESIA NOMOR 55 TAHUN 2007 TENTANG PENDIDIKAN AGAMA DAN PENDIDIKAN KEAGAMAAN. Hal 2, 6

${ }^{2}$ Wahyu A. Rini dkk, Bahan Ajar Matakuliah Etika UKI, 2014, 6-7
}

yang diilhamkan oleh Allah bermanfaat untuk mengajar, untuk menyatakan kesalahan, untuk memperbaiki kelakuan dan mendidik orang dalam kebenaran. Dengan demikian tiap-tiap manusia kepunyaan Allah diperlengkapi untuk perbuatan yang baik. ${ }^{3}$ Jelas disini bahwa pendidikan Agama Kristen merupakan inisiatif Tuhan, sejalan dengan hal tersebut, UKI dalam panggilannya untuk mengembangkan pendidikan karakter mahasiswa salah satunya melalui mata kuliah pendidikan Agama Kristen.

Menurut Thomas Groome

Pendidikan agama Kristen adalah kegiatan yang kompleks, dilaksanakan dalam konteks historis untuk memampukan orang-orang untuk hidup sebagai orangorang Kristen. ${ }^{4}$ Tujuan pendidikan agama Kristen adalah untuk memampukan orangorang hidup sebagai orang-orang Kristen, yaknihidup sesuai iman Kristen. yakni hidup sesuai iman Kristen. ${ }^{5}$ Menurut Homrighausen, hakekat pendidikan agama Kristen adalah pendidikan yang menyampaikan warisan gereja, keselamatan dinyatakan Allah dalam sejarah, di dalam diri Anak-Nya Yesus Kristus. Dengan pendidikan agama Kristen memasuki persekutuan yang hidup dengan Tuhan, dan oleh dan dalam Dia terhisap dalam persekutuan jemaat-Nya yang mengakui dan mempermuliakan

\footnotetext{
${ }^{3}$ Alkitab, LAI

${ }^{4}$ Groome H. Thomas. Christian Religius
} Education. (Jakarta: BPK Gunung Mulia. 2011), 37 ${ }^{5}$ Ibid 47 
Nama-Nyadi segala waktu dan tempat. ${ }^{6}$ Tugas pendidikan Kristen adalah mengantar pelajar sedemikian rupa, sehingga ia mengalami pengalaman yang benar dengan Allah, Bapa Tuhan Yesus Kristus. $^{7}$

Dari beberapa pendapat tersebut, bahwa pendidikan Agama Kristen adalah sebagai suatu usaha dikondisikan dan tersistem secara berkesinambungan untuk mengantar peserta didik mengalami hidup yang benar dengan Allah. Institusi pendidikan Kristen menjadi wadah dalam kesaksian nama Tuhan melalui pendidikan akademis, sebagaimana nasehat yang dikatakan oleh Yohanes Calvin dalam bukunya Institutio, Paulus menulis bahwa "untuk memenuhkan segala sesuatu", Kristus "memberikan baik rasul-rasul maupun nabi-nabi, baik pemberitapemberita Injil maupun gembala-gembala dan pengajar-pengajar, untuk memperlengkapi orang-orang kudus bagi pekerjaan pelayanan., bagi pembangunan tubuh Kristus, sampai kita semua telah mencapai kesatuan iman dan pengetahuan tentang Anak Allah, kedewasaan penuh, dan tingkat pertumbuhan yarg sesuai dengan kepenuhan Kristus" (Ef. 4:10). ${ }^{8}$ Pendidikan Agama Kristen merupakan pendidikan yang ikut membentuk pribadi mahasiswa untuk memiliki motivasi secara aktif untuk secara pribadi mengenal Yesus Kristus sebagai Tuhan dan Juruselamat, menebus umat manusia dari

${ }^{6}$ Homrigausen E.G dan I.H. Enklaar. Pendidikan Agama Kristen. (Jakarta: BPK Gunung Mulia. 2015), 19-24-26

${ }^{7}$ Robert R. Boehlke. Sejarah Perkembangan dan Praktek PAK: dari Yohanes Amos Comenius hingga Perkembangan PAK di Indonesia. (Jakarta: BPK-Gunung Mulia. 2003), 691

${ }^{8}$ Calvin, Yohanes. Instutio. Pengajaran Agama Kristen. (Jakarta: BPK Gunung Mulia, 2013), 229- 230. hukuman dosa (Yoh. 3:16; Rom. 10:9; Rom. 5:8-10; 1 Yoh. 5:13-15. ${ }^{9}$

Salah satu upaya untuk mewujudkan panggilan dan tugas Universitas Kristen Indonesia, adalah dengan memberikan mata kuliah Pendidikan Agama Kristen bagi mahasiswa. Tujuan Pendidikan Agama Kristen di UKI adalah: 1) agar mahasiswa mampu mengalami pengalaman perjumpaan dengan Tuhan dalam pengalaman keseharian sehingga dapat mengalami transformasi nilai-nilai kehidupan. 2) agar mahasiswa mampu menghayati kasih Allah dalam Yesus Kristus dengan bimbingan Roh Kudus sehingga dapat bertumbuh sebagai pribadi yg utuh. ${ }^{10}$

Mengacu pada Renstra UKI salah satu analisis, bahwa pembelajaran dengan paradigma Student Centered Learning masih perlu ditingkatkan; demikian pula, inovasi model pembelajaran yang efektif dalam proses belajar-mengajar juga masih perlu ditingkatkan. Perkembangan abad 21 ini menuntut perguruan tinggi menyelenggarakan pembelajaran yang memungkinkan lulusannya memiliki kemampuan kognitif tingkat tinggi, keterampilan memotivasi diri, keterampilan mengelola diri dan keterampilan teknis praktis. $^{11}$ Salah satu tugas mendidik mahasiswa adalah memotivasi mahasiswa untuk menjadi lulusan terbaik, berintegritas, peduli terhadap lingkungan dan berwawasan luas. Sejauh pengalaman mengajar mata kuliah Agama untuk mahasiswa angkatan 2016/2017, terdapat kecenderungan bahwa mahasiswa belum mengetahui dan memahami gaya belajar yang dimilikinya guna mengoptimalkan kecerdasan

${ }^{9}$ Ibid.

${ }^{10}$ Bahan Ajar Matakuliah Pendidikan

Agama Kristen UKI, 2008, 13

${ }^{11}$ Renstra UKI 2015-2019. 
majemuk, dengan demikian memunculkan pertanyaan apakah benar gaya belajar berpengaruh terhadap kecerdasan majemuk. Terdapat kecenderungan mahasiswa belum mengetahui dan memahami gaya belajar yang dimilikinya guna mengoptimalkan motivasi berprestasi, dengan demikian memunculkan pertanyaan apakah benar gaya belajar berpengaruh terhadap motivasi berprestasi. Terdapat kecenderungan mahasiswa belum mengetahui dan memahami kecerdasan majemuk yang dimilikinya guna mengoptimalkan motivasi berprestasi, dengan demikian memunculkan pertanyaan apakah benar kecerdasan majemuk berpengaruh terhadap motivasi berprestasi.

Sesuai Renstra UKI sasaran strategis 7 yaitu tercapainya mutu mahasiswa dan lulusan unggul dalam sikap, ketrampilan umum dan ketrampilan khusus dan pengetahuan, ${ }^{12}$ menjadi tugas dan tanggungjawab penulis dalam mengajar mata kuliah Agama untuk mendorong mahasiswa untuk dapat bertumbuh menjadi pribadi yang utuh, yang mampu memotivasi dirinya untuk menjadi pribadi yang unggul, dengan mengangkat masalah tentang pemahaman mahasiswa terhadap gaya belajar yang dimiliki dan kecerdasan dan pengaruhnya terhadap motivasi berprestasi.

\section{Tinjauan Teoritis}

\subsection{Gaya Belajar}

Menurut Gagne (1984), belajar dapat didefinisikan sebagai suatu proses di mana suatu organisasi berubah perilakunya sebagai akibat pengalaman. Secara teori kemampuan mahasiswa untuk memahami dan menyerap informasi yang disampaikan seorang dosen di kelas

\footnotetext{
12 Renstra UKI 2015-2019
}

melalui gaya belajar dan kecerdasan majemuk, di mana setiap individu memiliki perbedaan. ${ }^{13}$

Kemampuan manusia sebagai makhluk pembelajar, ditunjukan dalam aspek dirinya untuk berpikir, sehingga manusia dapat menimbang mana yang baik dan yang jahat dalam mengambil keputusan. Sebagai ciptaan Allah yang sangat berharga, kehidupan manusia berkembang baik secara fisik, mental maupun spiritual. Lukas 2:52 "Dan Yesus makin bertambah besar dan bertambah hikmat-Nya dan besar-Nya, dan makin dikasihi oleh Allah dan manusia".

Khoe Yao Tung dalam bukunya Pembelajaran dan Perkembangan Belajar, terdapat tiga gaya belajar yaitu: Visual, Auditory dan Kinestetik (VAK):

a. Visual: belajar dengan melihat (learn through seeing). Mahasiswa tipe ini lebih menyukai belajar melalui ekspresi dan bahasa tubuh untuk secara penuh memahami isi pelajaran tertentu. Mereka cenderung duduk di pusat perhatian atau paling depan kelas untuk menghindari penghalang visual (dari halangan murid lain). Mereka lebih mendapat gambaran dan berpikir dari tampilan visual yang mencakup: diagram, grafik, gambar animasi, transparansi, video atau alat penyaian informasi. Selama dalam kelas pelajar lebih baik menyerap informasi itu dengan tampilan visual. ${ }^{14}$

b. Auditory: belajar dengan mendengar (learn though listening). Mahasiswa tipe ini lebih menyenangi belajar melalui ceramah, kuliah lisan, diskusi, berbicara berbagai hal melalui tanya jawab, dan mendengarkan orang

${ }^{13}$ Ratna Wilis Dahar. Teori-teori Belajar dan Pembelajaran. (Jakarta: Erlangga, 2011), 2

${ }^{14}$ Khoe Yao Tung. Pembelajaran dan Perkembangan Belajar. (Jakarta: Indeks, 2005), 99-101 
tentang suatu hal. Murid ini mengggunakan indera pendengar untuk menginterpretasikan maksud informasi yang didapat dengan memperhatikan intonasi, nada suara, kecepatan berbicara, dan nuansa hati pembicara. Murid dengan gaya mendengar akan menyenangi belajar dengan membaca teks bacaan, yang dibunyikan dengan suara keras atau menggunakan alat perekam. ${ }^{15}$

c. (c)Kinestetik: belajar dengan menggunakan gerak (learn through tactile/kinesthetic). Mahasiswa tipe ini lebih menyenangi belajar melalui bergerak, melakukan dan menyentuh (moving, doing and tauching). Mahasiswa bergaya taktil/kinestetik lebih menyukaai belajar melalui pendekatan gerak langsung, yang bersentuhan dengan dunia fisik di sekitar mereka. Mereka membutuhkan gerak sebagai aktivitas untuk eksplorasi belajar mereka. ${ }^{16}$

Dari ketiga jenis gaya belajar yang dipaparkan di atas, menunjukkan keunikan dalam menyerap materi atau penjelasan dari seorang dosen, pemahaman tentang gaya belajar oleh seorang mahasiswa akan memberikan kontribusi pada hasil belajar secara optimal. Berpijak dari pendekatan student center learning, yaitu pembelajaran yang berpusat pada peserta didik, artinya bahwa peserta didik yang berperan aktif untuk berproses dalam menemukan pengetahuannya.

Michael Grinder, pengarang Righting the Education Conveyor Belt, telah mengajarkan gaya belajar dan mengajar kepada banyak instruktur. Ia mencatat bahwa dalam setiap kelompok yang terdiri dari tigapuluh murid sekitar

$$
\begin{aligned}
& 15 \text { Ibid. } \\
& { }^{16} \text { Ibid. }
\end{aligned}
$$

duapuluh dua orang mampu belajar secara cukup efektif dengan cara visual, auditorial, dan kinestetik sehingga mereka tidak membutuhkan perhatian khusus. ${ }^{17}$ Disini nampak secara mayoritas, rata-rata secara natural mahasiswa belajar secara efektif melalui visual, auditorial, dan kinestetik.

Dari sisa delapan orang, sekitar enam orang memilih satu modalitas belajar dengan sangat menonjol melebihi dua modalitas lainnya, sehingga setiap saat mereka harus selalu berusaha keras untuk memahami perintah, kecuali jika perhatian khusus diberikan kepada mereka dengan menghadirkan cara yang mereka pilih. Bagi orang-orang ini, mengetahui cara belajar terbaik mereka bisa berarti perbedaan antara keberhasilan dan kegagalan. Dua orang murid lainnya mempunyai kesulitan belajar karena sebab-sebab eksternal. ${ }^{18}$

The Dunn and Dunn VAK model is one of the most widely known and used theory of Learning style (Coffiel, Moseley, Hall \& Ecclestone,2004). The VAK learning style uses the three main sensory receivers: Visual, Auditory, and Kinaesthetic to determine the dominant learning style. It is sometimes known as VAKT (Visual, Auditory, Kinaesthetic, \& Tactile). It is based on modalities channels by which human expression can take place and is composed of a combination of perception and memory. VAK is derived from the accelerated learning world and seems to be about the most popular model due to its simplicity (Clark, 2011). ${ }^{19}$

${ }^{17}$ Bobby DePorter \& Mike Hernacki, Quantum Learning, (Bandung: Mizan, 1999), 112 114

${ }^{18}$ Ibid

${ }^{19}$ Omoniyi \& Olurinola. EDUCATIONAL MULTIMEDIA AND LEARNING STYLE PREFERENCES. British Journal of Education. 
Disini menunjukkan gaya belajar VAK menggunakan tiga penerima sensorik utama: Visual, Auditory, dan Kinaesthetic untuk menentukan gaya belajar yang dominan dan paling popular.

Hasil penelitian yang dilakukan oleh Petros dan Tod (2012) yaitu gaya belajar mahasiswa ditentukan oleh karakteristik bidang ilmu yang diambil di Old Dominion University. USA, di mana jumlah mahasiswa teknologi industri $(\mathrm{n}=$ 9) dan mahasiswa teknologi teknik ( $\mathrm{n}=$ 11) teknologi pendidikan $(n=17)$, gaya belajar dominan secara keseluruhan dalam kursus proses material adalah gaya kinestetik. $^{20}$

Hasil penelitian yang dilakukan oleh Jeanete dan Neleke melalui pendekatan kuantitatif dengan metode survey, dari 39 mahasiswa mahasiswa Program Studi Bimbingan dan Konseling FKIP Universitas Pattimura, diperoleh bahwa 6 mahasiswa memiliki kecenderungan gaya belajar visual, 20 mahasiswa memiliki kecenderungan gaya belajar auditorial, 1 mahasiswa memiliki kecenderungan gaya belajar kinestetik, dan 12 mahasiswa memiliki kecenderungan gaya belajar campuran antara gaya belajar visual dan gaya belajar auditorial. ${ }^{21}$

Vol.3, No.12, pp.29-42, December 2015, http://www.eajournals.org/wp-

content/uploads/Educational-Multimedia-andLearning-Style-Preferences.pdf diunduh 3 Fberuari 2017

${ }^{20}$ Petros and Todd D. Fantz . A

Comparative Analysis of Preferred Learning and Teaching Styles for Engineering, Industrial, and Technology Education Students and Faculty. Journal of Technology Education. Vol. 23 No. 2, Spring 2012, 61-69.

https://scholar.lib.vt.edu/ejournals/JTE/v23n2/pdf/

katsioloudis1.pdf. diunduh 5 Maret 2017.

${ }^{21}$ Jeanete dan Neleke (2016),

IDENTIFIKASI GAYA BELAJAR

MAHASISWA. Jurnal Psikologi Undip Vol.15

No.1 April 2016, 56-63.

\subsection{Kecerdasan Majemuk}

Pemahaman mengenai kecerdasan yang dimiliki manusia dalam konteks belajar merupakan sesuatu yang penting. Kajian kecerdasan manusia perlu dikemukakan, seperti yang dikemukakan oleh Howard Gardner tentang kecerdasan jamak (multiple intellegence) pada tahun 1983. Howard Gardner, seorang profesor psikologi di Harvard University Amerika Serikat, intellegence (kecerdasan) diartikan sebagai kemampuan untuk memecahkan persoalan dan menghasilkan produk dan dihargai dalam satu atau lebih lingkungan budaya ${ }^{22}$. Pemahaman konsep dan implementasi kecerdasan majemuk atau Mulipel Intelligence (MI) sangat penting bagi seorang mahasiswa, agar kualitas belajarnya dapat berkembang seiring dengan kecerdasan majemuk yang dimilikinya.

Multipel Intelligence dari Howard Gardner $^{23}$ : mula-mula Gardner mengelompokkan tujuh kecerdasan yaitu Linguistik, logical mathematical, bodily kinestetic, spatial, musical, interpersonal dan intrapersonal. Penjelasan ketujuh aspek kecerdasan dalam MI adalah sebagai berikut: (1) Linguistik kecerdasan ilmu bahasa dengan kemampuan pada sensitivitas suara, struktur, arti dan fungsi kata dan bahasa yang melibatkan kecerdasan dan kemampuan dalam hal menulis, membaca puisi, menceritakan cerita. Kemungkinan karier orang dengan kemampuan ini adalah penulis atau orator seperti Virginia

https://ejournal.undip.ac.id/index.php/psikologi/art icle/viewFile/12992/9731. Diunduh 12 April 2017.

${ }^{22}$ Eveline Siregar, Hartini Nara. Teori

Belajar dan Pembelajaran. (Bogor: Ghalia Indonesia, 2010), 99.

${ }^{23}$ Khoe Yao Tung. Pembelajaran dan Perkembangan Belajar. (Jakarta: Indeks, 2015), 94-96. 
Woolf, Marthin Luther King Jr. ${ }^{24}$ (2) Logical Mathematical- kecerdasan logika matematika: kemampuan mencerna pola nimerik, aturan operasi logika, kemampuan menangani rantai panjang penalaran yang melibatkan kemampuan memahami pola, kategori, hubungan, penyelesaian masalah matematika, permainan strategi, eksperimen pembuktian dalil. Kemungkinan karier orang dengan kemampuan ini adalah saintis atau ahli matematika seperti Madame Curie, Blaise Pascal. ${ }^{25}$ (3) Bodily - kinesthetic - kecerdasan kinestetik tunuh: kemampuan mengontrol gerakan dan menangani gerak dengan halus dan detail, yang melibatkan kecerdasan kan kemampuan dalam bidang atletik, menari, seni kerajinan tangan (jahitan, pekerjaan tukang kayu). Kemungkinan karier orang dengan kemampuan ini adalah atletik, penari, pematung, seperti: Jesse Owens, Martha Graham, Auguste Rodin. ${ }^{26}$ (4) Spatial - kecerdasan ruang: kemampuan merasakan dan memahami ruang visual secara akurat dan detail serta dapat mentransformasikan ke dalam persepsi ruang yang melibatkan pemecahan jalan yang semrawut, ukiran yang rumit dan kompleks, gambar dan imajinasi ruang. Kemungkinan karier orang dengan kemampuan ini adalah artis atau arsitek, seperti Fida Kahlo, I.M Pei. ${ }^{27}$ (5) Musical - kecerdasan musik: kemampuan untuk menghasilkan dan mengapresiasi ritma, pitch, dan warna bunyi untuk menampilkan ekspresi musik yang melibatkan kemampuan menyanyi, membuat aransemen musik; kemampuanmembedakan nada-nada musik. Kemungkinan karier bagi orang dengan kemampuan ini adalah composer, atau performer, seperti Stevie Wonder, Midori. ${ }^{28}$ (6) Interpersonal - kecerdasan terkait hubungan antar pribadi: kemampuan mencerna dan memahami, merespon mood, temperamen, motivasi dan hasrat orang lain yang melibatkan keterampilan kepemimpinan, komunikasi, pemahaman perasaan dari yang lain. Kemungkinan karier orang dengan kemampuan ini adalah konselor atau pemimpin politik, seperti Nelson Mandel dan Carl Rogers. ${ }^{29}$ (7) Intrapersonal kecerdasan mengelola mental diri: kemampuan mengontrol, merefleksikan perasaan dan emosi pribadi, serta memahami kekuatan dan kelemahan pribadi sendirei yang melibatkan pemahaman dan motivasi diri. Kemungkinan karier orang dengan kemampuan ini adalah psikoterapis atau pemimpin rohani, seperti Sigmund Freud, Billy Graham. ${ }^{30}$

Suarni Ni Ketut, dalam bukunya Metode Pengembangan Intelektual, menampilkan tabel kecocokan antara kemampuan yang menonjol pada suatu bidang dengan karakteristik seseorang ${ }^{31}$

Pada tahun 2000, kategori kecerdasan baru telah ditambahkan (kecerdasan yang kedelapan ${ }^{32}$ : Naturalist kecerdasan dan kesadaran yang melibatkan pemahaman, observasi dan organisasi lingkungan. Kemampuan ini melibatkan kepekaan akan keberadaan alam, tumnuhan dan hewan, observasi pada fenomena alam seperti Sacagewa, pegiat lingkungan dan pecinta alam.

28 Ibid.

29 Ibid

${ }^{30}$ Ibid.

${ }^{31}$ Suarni Ni Ketut. Metode Pengembangan Intelektual. (Yogyakarta: Graha Ilmu, 2014), 4-5

32 Khoe Yao Tung. Pembelajaran dan Perkembangan Belajar. (Jakarta: Indeks 2015), 95 
Kecerdasan majemuk merupakan anugerah bagi manusia sehingga manusia sanggup untuk berpikir, melakukan tindakan, serta mengambil keputusan untuk berperilaku dan menjadi tolok ukur bagi seorang mahasiswa atas kemampuannya dalam memecahkan masalah dan menciptakan produk yang bernilai budaya.

Hasil penelitian yang dilakukan oleh Fred dan Melody, tori kecerdasan majemuk adalah teori kecerdasan yang membedakannya menjadi modalitas yang spesifik, daripada melihat kecerdasan yang didominasi oleh kemampuan umum tunggal, seringkali disebut "faktor g." Howard Gardner telah mengidentifikasi sembilan kecerdasan berbeda. Teori ini telah muncul dari penelitian kognitif dan mendokumentasikan sejauh mana siswa memiliki jenis kecerdasan yang berbeda dan karena itu belajar dengan cara yang berbeda. $^{33}$

\subsection{Motivasi Berprestasi}

Motivasi berasal dari kata motif yaitu daya penggerak dalam diri seseorang untuk melakukan aktivitas tertentu, demi mencapai tujuan tertentu. Motivasi merupakan suatu kondisi yang mendorong atau menjadikan sebab seseorang melakukan suatu perbuatan/kegiatan, yang berlangsung secara sadar. Motivasi merupakan penggerak, sehingga memunculkan kegairahan untuk meningkatkan efektivitas belajar dan

\section{${ }^{33}$ Fred \& Melodt (2016). Applying} Multiple Intelligences in the Classroom: A Fresh Look at Teaching Writing. INTERNATIONAL JOURNAL OF SCHOLARLY ACADEMIC INTELLECTUAL DIVERSITY VOLUME 16, NUMBER 1, 2014, 1-13.

http://www.nationalforum.com/Electronic\%20Jour nal\%20Volumes/Lunenburg,\%20Fred\%20C\%20A pplying\%20Multiple\%20Intelligences\%20IJSAID $\% 20$ V16\%20N1\%202014.pdf. Diunduh 2 Februari 2017. mengaktifkan perilaku berprestasi dari mahasiswa. Berprestasi adalah idaman setiap individu, dengan adanya prestasi yang pernah diraih oleh seseorang akan menumbuhkan suatu semangat baru untuk menjalani aktifitas. Motivasi yang dibangun dapat memberikan pengaruh terhadap prestasi, di mana buah motivasi tersebut menghasilkan prestasi akademik yang lebih baik dan siap untuk bersaing di era global. ${ }^{34}$

Menurut Luthans, motivasi adalah proses sebagai langkah awal seseorang melakukan tindakan akibat kekurangan secara fisik dan psikis, yaitu suatu dorongan yang ditunjukan untuk memenuhi tujuan tertentu. Setiap kegiatan yang dilakukan oleh seseorang didorong oleh suatu kekuasaan dalam diri orang tersebut, kekuatan pendorong inilah yang disebut motivasi. ${ }^{35}$ Menurut Robbin, motivasi adalah keinginan untuk melakukan sebagai kesediaan untuk mengeluarkan tingkat upaya yang tinggi untuk tujuan-tujuan organisasi, yang dikondisikan oleh kemampuan upaya itu untuk memenuhi suatu kebutuhan individual ${ }^{36}$ Motivasi menunjukkan proses langkah awal untuk melakukan suatu gerakan-gerakan untuk mencapai suatu tujuan yang telah ditetapkan oleh organisasi sehingga dapat memenuhi kebutuhan secara individu. Motivasi merupakan serangkaian usaha untuk dapat menerima segala kondisi baik untuk yang disukai maupun tidak disukai untuk menggerakkan berekspresi. ${ }^{37}$

${ }^{34}$ Uno, Hamzah B. Teori Motivasi \& Pengukurannya Analisis di Bidang Pendidikan. (Jakarta: Bumi Aksara, 2007),3

35 Luthans, Fred, :" Perilaku Organisasi", Edisi Sepuluh, (Yogyakarta: Andi, 2016), 17.

${ }^{36}$ Robbins, Stephen P, "Perilaku Organisasi, Edisi kesepuluh, (Jakarta: PT Indeks , 2007), 29-30 
Motivasi berprestasi menurut McCelland (1917-1998) dasarnya adalah teori kebutuhan untuk mencapai prestasi atau Need for Achievement (N.Ach). Teorinya dikemukakan tahun 1953 dalam bukunya yang berjudul The Achievement Motive. Menurut teori ini seseorang memiliki ambisi, motivasi, dan bekerja keras untuk mencapai keberhasila. ${ }^{38}$ Motivasi berprestasi adalah sebuah prestasi yang menumbuhkan suatu semangat baru untuk menjalani aktifitas. Kebutuhan sukses merupakan kebutuhan untuk mencapai prestasi, reputasi, dan karier yang baik. Sedangkan kebutuhan untuk kekuasaan merupakan bentuk seseorang untuk mengendalikan lingkungannya dan terakhir kebutuhan berafiliasi adalah kebutuhan seseorang untuk berinteraksi dan behubungan dengan lingkungannya sehingga memiliki kekuatan untuk saling mempengaruhi. ${ }^{39}$

Menurut Mc.Celland, motivasi dapat dibedakan sesuai dengan kebutuhan seseorang untuk mencapai tujuannya. Ia menyebutkan terdapat tiga motivasi, yaitu kebutuhan berprestasi (N.Ach), kebutuhan berafiliasi (N. Aff), dan kebutuhan kekuasaan (N.Pow). Motivasi dalam psikologi pendidikan yang terpenting adalah N.Ach atau motivasi berprestasi. Murid berjuang untuk mencapai sukses atau memilih kegiatan yang berorientasi ke tujuan yang sukses. ${ }^{40}$ Berdasarkan pada uraian tersebut, bahwa motivasi merupakan suatu penggerak atau dorongan yang terdapat dalam diri manusia, yang dapat menimbulkan, mengarahkan, dan mengorganisasikan tingkah lakunya. Hal ini berhubungan

${ }^{38}$ Khoe Yao Tung. Pembelajaran dan Perkembangan Belajar. (Jakarta: Indeks 2015), 352-354.

39 Ibid.

40 Ibid. dengan upaya untuk memenuhi kebutuhan yang dirasakan dalam bentuk kebutuhan fisik maupun kebutuhan rohani.

\section{Rumusan Masalah}

1. Apakah gaya belajar mahasiswa berpengaruh terhadap kecerdasan majemuk?

2. Apakah gaya belajar mahasiswa berpengaruh terhadap motivasi berprestasi?

3. Apakah kecerdasan majemuk mahasiswa berpengaruh terhadap motivasi berprestasi?

\section{Tujuan Penelitian}

1. Untuk mengetahui pengaruh gaya belajar mahasiswa peserta mata kuliah agama Kristen terhadap kecerdasan majemuk.

2. Untuk mengetahui pengaruh gaya belajar mahasiswa peserta mata kuliah agama Kristen terhadap motivasi berprestasi.

3. Untuk mengetahui pengaruh kecerdasan majemuk mahasiswa peserta agama Kristen terdapat motivasi berprestasi.

\section{Hipotesis}

H1: Diduga gaya belajar mahasiswa berpengaruh terhadap kecerdasan majemuk .

H2: Diduga gaya belajar mahasiswa berpengaruh terhadap motivasi berprestasi.

H3: Diduga kecerdasan majemuk mahasiswa berpengaruh terhadap motivasi berprestasi.

\section{Metode Penelitian}

Jenis penelitian yang akan digunakan adalah pendekatan kuantitatif, dengan metode penelitian survey, yaitu penelitian yang mengambil sampel dari suatu populasi dan menggunakan kuisioner sebagai alat pengumpuldata. 
Mengacu pada tujuan penelitian yang telah ditetapkan, maka jenis penelitian ini bersifat penelitian eksplanatory research atau penelitian penjelasan, yaitu penelitian yang menjelaskan hubungan timbal balik antara variabel-variabel melalui pengujian hipotesis yang telah dirumuskan. ${ }^{41}$ Tempat penelitian di kampus UKI Jakarta, lokasi ini dipilih karena memenuhi semua aspek pendukung supaya penelitian ini dapat berjalan dengan lancar. Waktu penelitian dilaksanakan pada tgl 1 Mei sd 1 Agustus 2017.

Dalam penelitian ini populasi adalah mahasiswa peserta mata kuliah Agama Kristen di mana penulis sebagai dosen pengampu dari 3 kelas: Fakultas Sastra: 23 mahasiswa, Fakultas Teknik: 27 mahasiswa, Fakultas Ekonomi sejumlah 29 mahasiswa, total 79 mahasiswa Sampel pada penelitian ini akan diambil dari semua responden (penelitian jenuh). Kriteria sampel dalam penelitian ini adalah mahasiswa angkatan tahun 2016/2017.

Dalam penelitian ini teknik dan prosedur pengumpulan data dengan menggunakan kuisioner, melalui isian pada pertanyaan yang diajukan kepada mahasiswa peserta mata kuliah agama Kristen yang diampu penulis guna memperoleh informasi yang mendasarkan laporan tentang diri sendiri atau pada pengetahuan dan atau keyakinan pribadi subyek atau responden yang diteliti.

Kuesioner ini dimaksudkan untuk memperoleh data deskriptif guna menguji hipotesis. Untuk memperoleh data tersebut digunakan kuesioner yang bersifat tertutup yaitu pertanyaan yang dibuat sedemikian rupa hingga responden dibatasi dalam memberi jawaban kepada

${ }^{41}$ Singarimbun, M \& Effendi, S. Metode Penelitian Survey. (Jakarta: LP3ES. Volume 19, No.3, Oktober, 2011), 22-24. beberapa alternatif saja atau kepada satu jawaban saja. ${ }^{42}$

Mahasiswa sebagai responden mengisi kuesioner tersebut tanpa dilakukan wawancara agar jawaban yang diberikan tidak ada unsur intervensi dari peneliti. Setelah data kuisioner diisi oleh responden di kelas, maka peneliti langsung mengambil data tersebut.

\subsection{Metode Analisis Data dan Evaluasi Goodness of Fit Model PLS}

Untuk menguji hipotesis pertama sampai dengan hipotesis yang ketiga, dan menghasilkan suatu model yang layak (fit), maka analisis yang digunakan pada penelitian ini adalah menggunakan Partial Least Square (PLS) dengan proses perhitungan dibantu program aplikasi software Smart PLS. Alasan memakai model ini karena ada struktur hubungan yang berjenjang antar variabel, dan software ini sesuai dengan kebutuhan peneliti. $^{43}$

\section{Hasil Penelitian Dan Pembahasan}

\subsection{Gaya Belajar (X1)}

Para responden umumnya mempersepsikan bahwa gaya belajar memiliki tiga indikator yakni gaya belajar visual, gaya belajar auditory dan gaya belajar kinesthetic. ${ }^{44}$ Indeks persepsi responden terhadap gaya belajar visual diukur dari empat item yakni mudah mengingat dari apa yang lihat; mengerti materi perkuliahan dengan membaca

42 Nazir, M., Metode Penelitian, (Jakarta: Ghalia Indonesia, 2005), 3-4.

${ }^{43}$ Ghozali, Imam. Structural Equation

Modelling Metode Alternatif dengan Partial Least

Square. (Semarang: Badan Penerbit Universitas Diponegoro, 2011), 16-20.

${ }^{44}$ Khoe Yao Tung. Pembelajaran dan Perkembangan Belajar. (Jakarta: Indeks, 2015), 99-101. 
sendiri; mudah menjawab pertanyaan dengan menulis dan menyukai karya seni.

Indikator gaya belajar visual didapatkan nilai rata-rata sebesar 3,8296 dikategorikan baik. Para responden mempersepsikan bahwa gaya belajar visual yang diterapkan pada mata kuliah agama Kristen telah dilakukan sangat baik

Indikator gaya belajar auditory di ukur dengan empat item pertanyaan yakni mudah mengingat dari apa yang di dengar; mengerti materi perkuliahan melalui penjelasan; senang ditanya secara lisan dan terakhir menyukai musik.

Indikator gaya belajar auditory didapatkan nilai rata-rata sebesar 3,9716 dikategorikan baik. Para responden mempersepsikan bahwa gaya belajar auditory yang diterapkan pada mata kuliah agama kristen telah dilakukan dengan baik.

Indeks persepsi responden terhadap gaya belajar kinesthetic diukur dari empat item yakni mudah mengingat dengan cara berjalan atau menggerak-gerakkan kaki/tangan; mengerti materi perkuliahan apabila diterangkan dengan alat peraga; senang belajar dengan menulis ulang atau mengetik catatan pelajaran dan senang melakukan percobaan/membuat karya/eksperimen.

Untuk indikator gaya belajar kinesthetic didapatkan nilai rata-rata sebesar 3,7131 dikategorikan baik. Para responden mempersepsikan bahwa gaya belajar kinesthetic yang diterapkan pada mata kuliah agama kristen telah dilakukan baik.

Untuk Variabel gaya belajar didapatkan nilai rata-ratanya sebesar 3,8381 dengan ketiga indikator di atas yang terdiri atas gaya belajar visual dengan rata-rata 3,8296 , gaya belajar auditory dengan rata-rata 3,9716 dan gaya belajar kinesthetic dengan rata-rata 3,7131. Variabel gaya belajar yang dilaksanakan oleh mahasiswa pada perkuliahan agama kristen dilaksanakan dengan baik.

Hasil gaya belajar visual rata-rata menunjukkan kategori baik. Visual: belajar dengan melihat (learn through seeing). Mahasiswa peserta mata kuliah PAK rata-rata menyukai visual seperti gambar animasi, transparansi, video selama dalam kelas lebih menyerap informasi dengan tampilan visual. ${ }^{45}$

Hasil gaya belajar auditory rata-rata menunjukkan kategori baik. Mahasiswa peserta mata kuliah PAK menyenangi belajar melalui ceramah, kuliah lisan, diskusi, tanya jawab, membaca teks bacaan, yang dibunyikan dengan suara keras atau menggunakan alat perekam. ${ }^{46}$

Hasil gaya belajar kinesthetic ratarata menunjukkan kategori baik. Mahasiswa peserta mata kuliah PAK menyenangi belajar melalui bergerak, aktivitas untuk eksplorasi belajar. ${ }^{47}$ Belajar merupakan perubahan tingkah laku, kegiatan psiko fisik menuju pada perkembangan pribadi seutuhnya. ${ }^{48}$ Mahasiswa peserta mata kuliah Pendidikan Agama Kristen telah dapat mengaplikasikan gaya belajar secara Visual, Auditory dan Kinesthetic dengan baik. Bagi mahasiswa peserta mata kuliah PAK, gaya belajar merupakan satu modal untuk menjalankan panggilan hidup menjadi berkat melalui kesetiaan dan sukacita sebagaimana yang tertulis dalam Kisah Para Rasul 11:22-26 11:22 Maka sampailah kabar tentang mereka itu kepada jemaat di Yerusalem, lalu jemaat itu mengutus Barnabas ke

${ }^{45}$ Khoe Yao Tung. Pembelajaran dan Perkembangan Belajar. (Jakarta: Indeks, 2015), 99-101.

$$
\begin{aligned}
& { }^{46} \text { Ibid. } \\
& { }^{47} \text { Ibid. } \\
& { }^{48} \text { Ibid. }
\end{aligned}
$$


Antiokhia.11:23 Setelah Barnabas datang dan melihat kasih karunia Allah, bersukacitalah ia. Ia menasihati mereka, supaya mereka semua tetap setia kepada Tuhan, 11:24 karena Barnabas adalah orang baik, penuh dengan Roh Kudus dan iman. Sejumlah orang dibawa kepada Tuhan.

\subsection{Kecerdasan Majemuk (X2)}

Kecerdasan majemuk adalah kemampuan untuk memecahkan persoalan dan menghasilkan produk dalam suatu situasi yang beragam dan nyata. Indikator yang diukur dari kecerdasan majemuk adalah sebagai berikut: kecerdasan linguistik, kecerdasan logical mathematical, kecerdasan bodily kinestetic, kecerdasan spatial, kecerdasan musical, kecerdasan interpersonal, kecerdasan intrapersonal, dan kecerdasan naturalis. ${ }^{49}$

Indeks persepsi responden terhadap kecerdasan linguistik diukur dari empat item yakni membuat karya tulis, membaca puisi, senang bercerita dan senang berpidato.

Untuk indikator kecerdasan linguistik didapatkan nilai rata-rata sebesar 3,3381 dikategorikan cukup. Para responden menunjukkan bahwa kecerdasan linguistik dari mahasiswa peserta mata kuliah agama Kristen cukup.

Indeks persepsi responden terhadap kecerdasan logical mathematical diukur dari tiga item yakni senang berhitung dan bermain angka; senang berhitung dan bermain angka; dan senang permainan strategi dan problem solving.

Untuk indikator kecerdasan logical mathematical didapatkan nilai rata-rata sebesar 3,5454 dikategorikan baik. Para responden mempersepsikan bahwa

${ }^{49}$ Sardiman. Interaksi \& Motivasi Belajar Mengajar. (Jakarta: Rajawali Press, 2016), 20-23. kecerdasan logical mathematical yang diterapkan pada mata kuliah agama kristen telah baik dilakukan..

Indeks persepsi responden terhadap kecerdasan bodily kinestetic diukur dari empat item yakni dapat mengontrol keseimbangan tubuh dengan baik, menyukai bidang atletik/olah raga, menyukai bidang seni tari dan mampu bermain peran.

Untuk indikator kecerdasan bodily kinestetic didapatkan nilai rata-rata sebesar 3,6534 dikategorikan baik. Para responden mempersepsikan bahwa Kecerdasan bodily kinestetic yang diterapkan pada mata kuliah agama kristen baik telah dilakukan.

Indeks persepsi responden terhadap kecerdasan spatial diukur dari tiga item yakni mampu mendesain ruang; memiliki kepekaan terhadap warna; dan memiliki kemampuan menggambar.

Untuk indikator kecerdasan spatial di dapatkan nilai rata-rata sebesar 3,5682 dikategorikan baik. Para responden mempersepsikan bahwa Kecerdasan spatial yang diterapkan pada mata kuliah agama kristen baik telah dilakukan.

Indeks persepsi responden terhadap kecerdasan musical diukur dari tiga item yakni memiliki kepekaan terhadap nada; memiliki kemampuan memainkan alat musik; memiliki kemampuan menyanyi.

Untuk indikator kecerdasan musical di dapatkan nilai rata-rata sebesar 3,5151 dikategorikan baik. Para responden mempersepsikan bahwa Kecerdasan musical yang diterapkan pada mata kuliah agama kristen baik telah dilakukan.

Indeks persepsi responden terhadap kecerdasan interpersonal diukur dari dua item yakni mudah bergaul/berteman, dan memiliki kemampuan memotivasi orang lain.

Untuk indikator kecerdasan interpersonal di dapatkan nilai rata-rata 
sebesar 3,8693 dikategorikan baik. Para responden mempersepsikan bahwa kecerdasan interpersonal yang diterapkan pada mata kuliah agama kristen telah baik dilakukan.

Indeks persepsi responden terhadap kecerdasan intrapersonal diukur dari tiga item yakni memahami gambar dirinya: kekuatan dan kelemahan diri, memiliki kemampuan untuk merefleksikan perasaan dan memiliki kemampuan memotivasi diri sendiri.

Untuk indikator kecerdasan intrapersonal didapatkan nilai rata-rata sebesar 3,9486 dikategorikan baik. Para responden mempersepsikan bahwa kecerdasan intrapersonal yang diterapkan pada mata kuliah agama kristen baik telah dilakukan.

Indeks persepsi responden terhadap kecerdasan naturalis diukur dari tiga item yakni senang melakukan obsservasi lapangan, senang melihat ciptaan Tuhan: keragaman hewan dan tumbuhan dan senang terlibat dalam organisasi lingkungan hidup.

Untuk indikator kecerdasan naturalis didapatkan nilai rata-rata sebesar 4,1629 dikategorikan baik. Para responden mempersepsikan bahwa Kecerdasan naturalis yang diterapkan pada mata kuliah agama kristen telah dilakukan dengan baik..

Untuk Variabel kecerdasan majemuk didapatkan nilai rata-ratanya sebesar 3,7001 dengan kategori baik yang terdiri atas delapan indikator yakni: kecerdasan linguistik nilai rata-rata sebesar 3,3381; kecerdasan logical mathematical nilai rata-rata sebesar 3,5454; kecerdasan bodily kinestetic nilai rata-rata sebesar 3,6534; kecerdasan spatial nilai rata-rata sebesar 3,5682; kecerdasan musical nilai rata-rata sebesar 3,5151; kecerdasan interpersonal nilai rata-rata sebesar 3,8693; kecerdasan intrapersonal nilai rata-rata sebesar 3,9486; dan kecerdasan naturalis nilai rata-rata sebesar 4,1629. Variabel kecerdasan majemuk yang dilaksanakan oleh mahasiswa pada perkuliahan agama kristen didapatkan baik.

Hasil menunjukkan kecerdasan lingusistik rata-rata cukup, di mana mahasiswa cukup memiliki kemampuan mahasiswa dalam menggunakan kata-kata secara terampil dan mengkespresikan konsep-konsep secara fasih dari mahasiswa dari peserta mata kuliah Agama Kristen. Untuk item menang membaca puisi mendapat kategori cukup dan senang berpidato mendapat kategori cukup. Namun untuk item senang membuat karya tulis dengan kategori baik, dan item senang berceritera dengan kategori baik. Mahasiswa memiliki kemungkinan karier orang dengan kemampuan ini adalah penulis atau orator seperti Virginia Woolf, Marthin Luther King Jr. ${ }^{50}$ Dramawan, Editor, Penulis, Pengarang, Jurnalis, Pengacara, Guru, Orator. ${ }^{51}$

Kecerdasan logical mathematical yang merupakan kemampuan dalam memahami analitik dan saintifik. Untuk item senang berhitung dan bermain angka mendapat dengan kaegori cukup, namun rata-rata dengan kategori baik. Menurut Howard Gardner, kecerdasan logismatematis menjadi dasar daripada kecerdasan-kecerdasan yang lain: lebih dasar, dalam pengertian konseptual. ${ }^{52}$ Mahasiswa memiliki kemungkinan karier orang dengan kemampuan ini adalah saintis atau ahli matematika seperti

${ }^{50}$ Khoe Yao Tung. Pembelajaran dan Perkembangan Belajar. Jakarta: Indeks (2015), 94-96.

${ }^{51}$ Suarni Ni Ketut. Metode Pengembangan Intelektual. (Yogyakarta: Graha Ilmu, 2014), 4-5.

52 Agus Efendi. Revolusi Kecerdasan Abad 21. (Bandung: Alfabeta, 2005), 144-145. 
Madame Curie, Blaise Pascal. ${ }^{53}$ Logikus, Matematikus, Akuntan, Saintis, Teknisi, Programmer. ${ }^{54}$

Hasil kecerdasan bodily kinestetic didapatkan nilai rata-rata kategori baik. Kecerdasan ini manfaatnya akan semakin terasa ketika kebugaran otak (brain fitness), yang dipandang sebagai pusat kecerdasan, sangat berkaitan dengan kecerdasan tubuh. Kecerdasan tubuh adalah kemampuan memahami, mencintai dan memelihara tubuh. Kecerdasan tubuh ini memungkinkan terjadinya hubungan antara pikiran dan tubuh yang diperlukan agar berhasil dalam berbagai aktivitas seperti menari, melakukan pantomim, berolah raga, memainkan drama serta menguasai seni bela diri. ${ }^{55}$ Mahasiswa memiliki kemungkinan karier orang dengan kemampuan ini adalah atletik, penari, pematung, seperti: Jesse Owens, Martha Graham, Auguste Rodin. ${ }^{56}$ Aktor, Atlet, Penari, Pemahat, Ahli Bedah, Sportmen, Stormen, Teknisi berbagai pekerjaan keterampilan. ${ }^{57}$

Hasil kecerdasan spatial didapatkan nilai rata-rata kategori baik. Kecerdasan ini merupakan kemampuan untuk memberikan gambar-gambar dan imagiimagi, serta kemampuan dalam mentransformasikan dunia visual spatial. Kecerdasan tersebut penting mengorientasikan dan mengenali objek

${ }^{53}$ Khoe Yao Tung. Pembelajaran dan Perkembangan Belajar. (Jakarta: Indeks, 2015), 94-96.

${ }^{54}$ Suarni Ni Ketut. Metode Pengembangan Intelektual. (Yogyakarta: Graha Ilmu, 2014), 4-5.

55 Agus Efendi. Revolusi Kecerdasan Abad 21. (Bandung: Alfabeta, 2005), 144-152.

${ }^{56}$ Khoe Yao Tung. Pembelajaran dan Perkembangan Belajar. Jakarta: Indeks (2015), 94-96.

57 Suarni Ni Ketut. Metode Pengembangan Intelektual. (Yogyakarta: Graha Ilmu, 2014), 4-5. serta pemandangan di lingkungan aslinya, kecerdasan ini sangat bermanfaat untuk membuat lukisan grafis dua atau tiga dimensi atau simbol-simbol seperti peta, diagram atau bentuk-bentuk geometrik. ${ }^{58}$ Kemungkinan karier orang dengan kemampuan ini adalah artis atau arsitek, seperti Fida Kahlo, I.M Pei. ${ }^{59}$ Pemburu, Arsitek, Decorator, Fotografer, Seniman, Navigator. ${ }^{60}$

Hasil kecerdasan musik didapatkan nilai rata-rata kategori baik, namun untuk item kemampuan memainkan musik kategori cukup. Musik adalah pengunggah perasaan mendalam yang paling cepat, merupakan kesatuan yang tak terpisahkan dengan kehidupan manusia. Bahkan adalah entitas yang sangat menyatu dengan kesadaran transendental manusia. Tabuhan ritmis dalam erbagai ritus spiritual dapat mengaktifkan lobus temporal berikut area sistem limbik yang berkaitan dengannya. Musik dapat menghilangkan stress dan meningkatkan fungsi otak, menurut hasil penelitian, pelajar yang mendengarkan musik Mozard mendapatkan nilai lebih tinggi dalam standar tes IQ dibandingkan dengan mahasiswa yang menghabiskan waktu dan berdiam diri. ${ }^{61}$ Kemungkinan karier bagi orang dengan kemampuan ini adalah composer, atau performer, seperti Stevie Wonder, Midori. ${ }^{62}$ Pemusik, Pencipta Lagu, Penyanyi, Penggubah/Aransemen

58 Agus Efendi, Revolusi Kecerdasan Abad 21, (Bandung: Alfabeta, 2005), 144-152.

${ }^{59}$ Khoe Yao Tung. Pembelajaran dan Perkembangan Belajar. Jakarta: Indeks (2015), 9496.

${ }^{60}$ Suarni Ni Ketut. Metode Pengembangan Intelektual. (Yogyakarta: Graha Ilmu, 2014), 4-5.

61 Agus Efendi, Revolusi Kecerdasan Abad 21, (Bandung: Alfabeta, 2005), 144-152.

${ }^{62}$ Khoe Yao Tung. Pembelajaran dan Perkembangan Belajar. Jakarta: Indeks (2015), 94-96. 
lagu. ${ }^{63}$

Hasil kecerdasan interpersonal didapatkan nilai rata-rata kategori baik. Dalam psikologi, studi mengenai teori kepribadian, memandang bahwa penting dan sentralnya diri pribadi dalam membangun konsep kepribadian, pertumbuhan dan nasibnya. Kecerdasan interpersonal merupakan kecerdasan yang bergerak keluar, kepada individu-individu yang lain. Merupakan kecerdasan dalam mencatat dan membedakan individuindividu dan khususnya suasana (moods), temperamen, motivasi, kecerdasan yang ditunjukkan dengan kemampuan memahami dan berinteraksi dengan orang lain. ${ }^{64}$ Kemungkinan karier orang dengan kemampuan ini adalah konselor atau pemimpin politik, seperti Nelson Mandel dan Carl Rogers. ${ }^{65}$ Konselor, Psikolog, Guru, Dokter, Perawat. ${ }^{66}$

Hasil kecerdasan intrapersonal didapatkan nilai rata-rata kategori baik. Kecerdasan intrapersonal adalah kecerdasan yang bergerak ke dalam, merupakan kecerdasan dalam membedakan perasaan-perasaan, yang menggambarkan kekayaan pengalaman bathin. ${ }^{67}$ Kemungkinan karier orang dengan kemampuan ini adalah psikoterapis atau pemimpin rohani, seperti Sigmund Freud, Billy Graham.

${ }^{63}$ Suarni Ni Ketut. Metode Pengembangan Intelektual. (Yogyakarta: Graha Ilmu, 2014), 4-5.

${ }^{64}$ Agus Efendi, Revolusi Kecerdasan Abad 21, (Bandung: Alfabeta, 2005), 147-149.

${ }^{65}$ Khoe Yao Tung. Pembelajaran dan Perkembangan Belajar. Jakarta: Indeks (2015), 94-96.

${ }^{66}$ Suarni Ni Ketut. Metode Pengembangan Intelektual. (Yogyakarta: Graha Ilmu, 2014), 4-5.

67 Agus Efendi, Revolusi Kecerdasan Abad 21, (Bandung: Alfabeta, 2005), 150-156.

${ }^{68}$ Khoe Yao Tung. Pembelajaran dan Perkembangan Belajar. Jakarta: Indeks (2015), 94-96.
Penasehat, rohaniawan, Filosof, Pemikir, Pencipta karya keilmuan. ${ }^{69}$

Hasil kecerdasan naturalis didapatkan nilai rata-rata kategori baik. Merupakan kemampuan ini melibatkan kepekaan akan keberadaan alam, tumbuhan dan hewan, observasi pada fenomena alam, pegiat lingkungan dan pecinta alam. ${ }^{70}$

Manusia diciptakan segambar dengan Allah (Kejadian 1: 26-28), manusia merupakan mahluk ciptaan Allah yang tidak sama dengan ciptaan yang lain. Manusia memiliki kemampuan untuk berpikir di mana secara teori manusia memiliki kecerdasan yang majemuk/kompleks. Mahasiswa sebagaimana manusia yang diciptakan segambar dengan rupa Allah, dengan kecerdasannya yang majemuk, mampu untuk berpikir secara rasional, memiliki keterampilan dan daya seni, mampu mengambil keputusan untuk hidup bertanggungjawab. Kecerdasan tersebut merupakan atribut dan bekal bagi mahasiswa untuk dapat mengarungi kehidupan dan masa depannya, apabila dilaksanakan dengan hikmat. Sebagaimana tertulis dalam Amsal 1:7a, Takut akan Tuhan adalah permulaan pengetahuan. Amsal 15:33 Takut akan TUHAN adalah didikan yang mendatangkan hikmat, dan kerendahan hati mendahului kehormatan.

\subsection{Motivasi Mahasiswa Berprestasi (X3)}

Motivasi berprestasi adalah suatu daya atau kekuatan atau energi dalam mental atau pikiran manusia untuk melakukan suatu kegiatan yang lebih baik,

${ }^{69}$ Suarni Ni Ketut. Metode Pengembangan Intelektual. (Yogyakarta: Graha Ilmu, 2014), 4-5.

${ }^{70}$ Khoe Yao Tung. Pembelajaran dan Perkembangan Belajar. Jakarta: Indeks (2015), 95. 
lebih cepat, lebih efektif dan lebih efisien daripada kegiatan yang dilaksanakan sebelumnya maupun yang dilakukan atau dicapai orang lain, yang dapat diukur. ${ }^{71}$ Indikator yang diukur dari motivasi mahasiswa berprestasi adalah sebagai berikut: memiliki preferensi untuk mengerjakan tugas-tugas, menyukai situasi-situasi di mana kinerja mereka timbul karena upaya upaya sendiri, dan menyukai umpan balik tentang tugas yang diberikan.

Indeks persepsi responden terhadap indikator memiliki preferensi untuk mengerjakan tugas-tugas diukur dari dua item yakni senang bekerja keras dan senang menjadi panutan teman-teman tentang kesuksesan dalam belajar. Telaah lebih lanjut untuk setiap item pertanyaan untuk memiliki

Untuk indikator memiliki preferensi untuk mengerjakan tugas-tugas dengan bekerja keras, dan menjadi panutan bagi teman untuk sukses belajar, didapatkan nilai rata-rata sebesar 4,0909 dikategorikan baik. Para responden mempersepsikan bahwa memiliki preferensi untuk mengerjakan tugas-tugas yang diterapkan pada mata kuliah agama Kristen baik dan telah dilakukan.

Indeks persepsi responden terhadap indikator menyukai situasi-situasi di mana kinerja mereka timbul karena upaya-upaya sendiri diukur dari dua item yakni berusaha menyelesaikan tugas secara mandiri dan mampu menganalisis untuk mendapatkan cara pemecahan terbaik terhadap setiap masalah yang dihadapi.

Untuk indikator menyukai situasisituasi di mana kinerja mereka timbul karena upaya upaya sendiri didapatkan nilai rata-rata sebesar 3,9603 dikategorikan baik. Para responden mempersepsikan bahwa menyukai situasi-

\footnotetext{
${ }^{71}$ Ibid 352.
}

situasi di mana kinerja mereka timbul karena upaya-upaya sendiri yang diterapkan pada mata kuliah agama kristen baik telah dilakukan.

Indeks persepsi responden terhadap indikator menyukai umpan balik tentang tugas yang diberikan diukur dari dua item yakni senang menerima masukan untuk tugas yang dikerjakan dan senang menerima tugas-tugas yang menantang/ hal baru.

Untuk indikator menyukai umpan balik tentang tugas yang diberikan didapatkan nilai rata-rata sebesar 4,0909 dikategorikan baik. Para responden mempersepsikan bahwa menyukai umpan balik tentang tugas yang diberikan yang diterapkan pada mata kuliah agama Kristen baik dan telah dilakukan. Di mana mahasiswa mempersepsikan bahwa semua besar item pertanyaan memiliki nilai ratarata berada di antara 3,400 sampai dengan 4,200.

Untuk Variabel motivasi berprestasi mahasiswa didapatkan nilai rata-ratanya sebesar 4,0474 dengan kategori baik yang terdiri atas tiga indikator yakni: memiliki preferensi untuk mengerjakan tugas-tugas dengan nilai rata-rata sebesar 4,0909; menyukai situasi-situasi di mana kinerja mereka timbul karena upaya upaya sendiri didapatkan nilai rata-rata sebesar 3,9603 dan menyukai umpan balik tentang tugas yang diberikan didapatkan nilai rata-rata sebesar 4,0909. Variabel motivasi berprestasi mahasiswa yang dilaksanakan oleh mahasiswa pada perkuliahan agama Kristen didapatkan baik.

Hasil tersebut memberikan makna penting dalam mendorong mahasiswa untuk memelihara motivasi berprestasi yang dimiliki. Motivasi dalam psikologi pendidikan yang terpenting adalah N.Ach atau motivasi berprestasi. Mahasiswa berjuang untuk mencapai sukses atau memilih kegiatan yang berorientasi ke 
tujuan yang sukses. ${ }^{72}$ Sejalan dengan pendapat Luthans, motivasi adalah proses sebagai langkah awal seseorang melakukan tindakan akibat kekurangan secara fisik dan psikis, yaitu suatu dorongan yang ditunjukkan untuk memenuhi tujuan tertentu. ${ }^{73}$ Motivasi tumbuh didorong oleh kebutuhan (need) seseorang, dan motivasi tersebut berkembang mengikuti aktivitas untuk memenuhi kebutuhan tersebut. ${ }^{74}$ Motivasi berprestasi adalah sebuah prestasi yang menumbuhkan suatu semangat baru untuk menjalani aktivitas. Motivasi ibarat kekuatan mesin yang berkekuatan tinggi menjamin lajunya kendaraan untuk mendaki dan membawa muatan yang berat. ${ }^{75}$ Sebagai generasi muda semangat berprestasi perlu dipupuk, tertuang dalam data di mana para mahasiswa peserta mata kuliah Agama Kristen senang bekerja keras dalam melakukan tugas-tugas, dan senang menjadi panutan teman-teman tentang kesuksesan dalam belajar dengan hasil hitung sangat baik. Hal ini sangat penting untuk menjadi bekal menapaki masa depan mahasiswa melalui kesenangannya belajar, mengasah akal budi untuk mendapatkan prestasi. Sebagaimana tertulis dalam Alkitab di Mazmur 42:1 Untuk pemimpin biduan. Nyanyian pengajaran bani Korah. Mazmur 47:7 7:8 Bermazmurlah bagi Allah, bermazmurlah, bermazmurlah bagi Raja kita, bermazmurlah!, 47:8 Sebab Allah adalah Raja seluruh bumi, bermazmurlah dengan nyanyian pengajaran, Amsal 12:1a Siapa mencintai didikan, mencintai pengetahuan; Roma

72 Ibid.

73 Luthans, Fred. "Perilaku Organisasi". Edisi Sepuluh, (Yogyakarta: Andi, 2006), 17.

${ }^{74}$ Martinis Yamin,. Strategi Pembelajaran Berbasis Kompetensi. (Jakarta: Gaung Persada Press, 2004), 80-81.

75 Ibid.
3:11 Tidak ada seorang pun yang berakal budi, tidak ada seorang pun yang mencari Allah. Roma 8:28, Allah bekerja dalam segala sesuatu mendatangkan kebaikan bagi orang-orang yang mengasihi Dia.

\subsection{Hasil Uji Validitas dan Reliabilitas Convergent Validity}

Korelasi antara skor indikator refleksif dengan skor variabel latennya. Indikator individu dianggap reliable jika memiliki nilai korelasi atau loading 0.5 sampai 0.6. Nilai korelasi ini dianggap cukup karena merupakan tahap awal pengembangan skala pengukuran dan jumlah indikator per konstruk tidak besar, berkisar antara 3 sampai 7 indikator. Hal ini terlihat pada hubungan antara indikator dengan konstruk yang terdapat pada Gambar 4.1 yang ditunjukkan pada nilai outer loadings. Hasil model struktural yang diteliti menunjukkan hubungan antara indikator dengan masing-masing variabel yang ditunjukkan dengan besarnya nilai bobot faktor. ${ }^{76}$ Variabel pertama yakni Gaya belajar sebagai variabel diukur dari tiga indikator yakni gaya belajar visual dengan loading factor 0,839; gaya belajar auditorial dengan loading factor 0,795; dan gaya belajar kinestetik prestasi kerja dengan loading factor 0,609. Berdasarkan pada Gambar 4.1 hasil pada uji Convergent validity didapatkan bahwa semua indikator pada variabel gaya belajar berada di atas 0,5 dan memenuhi uji validitas.

${ }^{76}$ Ghozali, Imam. Structural Equation Modelling Metode Alternatif dengan Partial Least Square. (Semarang: Badan Penerbit Universitas Diponegoro, 2011), 30-34. 


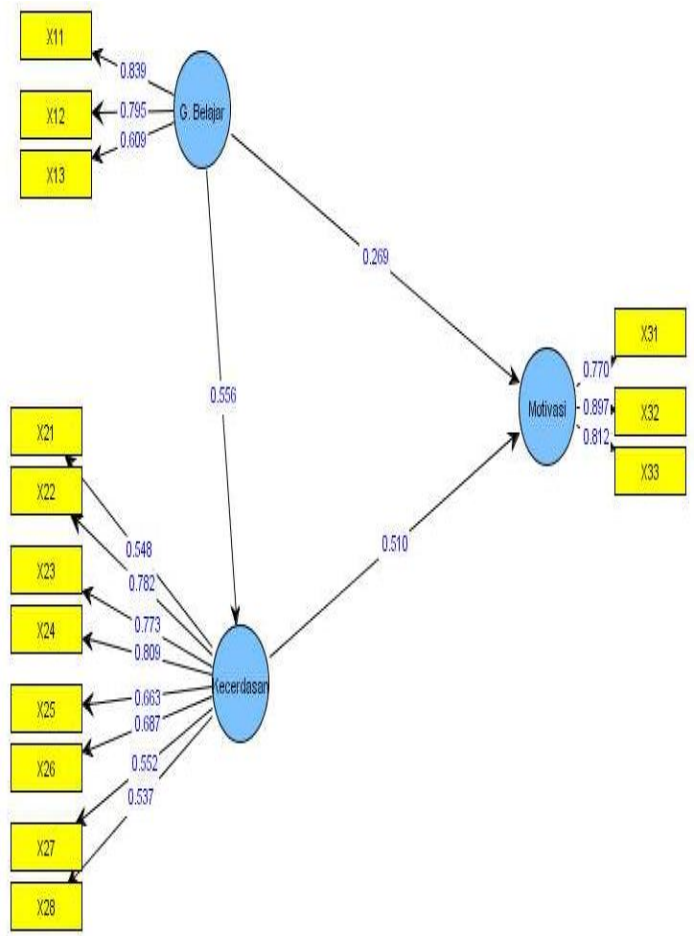

Gambar 4.1. Convergent Validity

Convergent validity pada variabel kecerdasan majemuk yang diukur dari delapan indikator yakni kecerdasan linguistik dengan loading factor 0,548; kecerdasan logika matematika dengan loading factor 0,782; kecerdasan visualspasial dengan loading factor 0,773; kecerdasan bodily kinestetik dengan loading factor 0,809; kecerdasan musikal dengan loading factor 0,663; kecerdasan interpersonal dengan loading factor 0,687; kecerdasan intrapersonal dengan loading factor 0,552 dan kecerdasan naturalis dengan loading factor 0,537. Berdasarkan pada Gambar 4.3 hasil pada uji Convergent validity didapatkan bahwa semua indikator pada variabel kecerdasan majemuk berada di atas 0,5 dan memenuhi uji validitas.

Convergent validity pada variabel motivasi berprestasi mahasiswa dengan indikator memiliki preferensi untuk mengerjakan tugas-tugas dengan loading factor 0,770; menyukai situasi-situasi di mana kinerja mereka timbul karena upaya upaya sendiri dengan loading factor 0,897 dan ketiga menyukai umpan balik tentang tugas yang diberikan dengan loading factor 0,812. Berdasarkan pada Gambar 4.3 hasil pada uji Convergent validity didapatkan bahwa semua indikator pada variabel motivasi berprestasi mahasiswa berada di atas 0,5 dan memenuhi uji validitas. Berdasarkan pada Gambar 4.3 hasil pada uji Convergent validity didapatkan bahwa semua indikator pada seluruh variabel penelitian telah berada di atas 0,5 ; Sehingga dapat dilakukan proses bootstraping.

\subsection{Pengujian Hipotesis Penelitian}

\subsubsection{Pengujian Outer Model ${ }^{77}$}

Berdasarkan pada Tabel 4.1, koefisien lamda ( $\lambda \mathrm{i}$ ) untuk X11 (gaya belajar visual) sebesar $0,839>0,5$ dan $T$ statistic sebesar 17,330 > T tabel sebesar 1,96. Hal ini menunjukkan bukti bahwa indikator gaya belajar visual sebagai instrument variabel gaya belajar dengan taraf signifikan pada 0,05 . X12 (gaya belajar auditorial) sebesar 0,795 >0,5 dan T-statistic sebesar 6,974 > T tabel sebesar 1,96. Hal ini menunjukkan bukti bahwa indikator gaya belajar auditorial sebagai instrument variabel gaya belajar dengan taraf signifikan pada 0,05 .

Tabel .4.1 Hasil Cross Loading pada Output PLS

\begin{tabular}{|c|c|c|c|c|}
\hline & $\begin{array}{c}\text { origina } \\
\text { sample } \\
\text { estimat } \\
\mathrm{e}\end{array}$ & $\begin{array}{c}\text { mean of } \\
\text { subsampl } \\
\text { es }\end{array}$ & $\begin{array}{c}\text { Standar } \\
\mathrm{d} \\
\text { deviatio } \\
\mathrm{n}\end{array}$ & $\begin{array}{c}\mathrm{T} \text { - } \\
\text { Statisti } \\
\mathrm{c}\end{array}$ \\
\hline G. Belajar & & & & \\
\hline $\mathrm{X} 11$ & 0.839 & 0.866 & 0.048 & 17.330 \\
\hline $\mathrm{X} 12$ & 0.795 & 0.748 & 0.114 & 6.974 \\
\hline
\end{tabular}




\begin{tabular}{|c|c|c|c|c|}
\hline & $\begin{array}{c}\text { origina } \\
\text { sample } \\
\text { estimat } \\
\text { e }\end{array}$ & $\begin{array}{c}\text { mean of } \\
\text { subsampl } \\
\text { es }\end{array}$ & $\begin{array}{c}\text { Standar } \\
\mathrm{d} \\
\text { deviatio } \\
\mathrm{n}\end{array}$ & $\begin{array}{c}\text { T- } \\
\text { Statisti } \\
\mathrm{c}\end{array}$ \\
\hline X13 & 0.609 & 0.523 & 0.152 & 4.009 \\
\hline $\begin{array}{c}\text { Kecerdas } \\
\text { an }\end{array}$ & & & & \\
\hline X21 & 0.548 & 0.571 & 0.121 & 4.526 \\
\hline X22 & 0.782 & 0.784 & 0.057 & 13.758 \\
\hline X23 & 0.773 & 0.772 & 0.044 & 17.589 \\
\hline X24 & 0.809 & 0.802 & 0.051 & 15.755 \\
\hline X25 & 0.663 & 0.633 & 0.099 & 6.711 \\
\hline X26 & 0.687 & 0.646 & 0.091 & 7.578 \\
\hline X27 & 0.552 & 0.549 & 0.097 & 5.675 \\
\hline X28 & 0.537 & 0.537 & 0.097 & 5.511 \\
\hline Motivasi & & & & \\
\hline X31 & 0.770 & 0.759 & 0.078 & 9.890 \\
\hline X32 & 0.897 & 0.901 & 0.023 & 39.084 \\
\hline X33 & 0.812 & 0.806 & 0.075 & 10.873 \\
\hline Sumber & Hasil & \\
\hline
\end{tabular}

Sumber : Hasil PLS dari pengolahan data primer (2017)

Tabel 4.1 menunjukkan bahwa variabel gaya belajar dengan indikator X13 (gaya belajar kinestetik prestasi kerja) sebesar 0,609 > 0,5 dan T-statistic sebesar 4,009 > T tabel sebesar 1,96. Hal ini menunjukkan bukti bahwa indikator gaya belajar kinestetik sebagai instrument variabel gaya belajar dengan taraf signifikan pada 0,05 .

Variabel kecerdasan majemuk pada Tabel 4.1 menunjukkan bahwa indikator X21 (kecerdasan linguistik) sebesar 0,548 $>0,5$ dan T-statistic sebesar 4,526 > T tabel sebesar 1,96. Hal ini menunjukkan bukti bahwa indikator kecerdasan linguistik sebagai instrument variabel kecerdasan majemuk dengan taraf signifikan pada 0,05. Indikator X22 (kecerdasan logika matematika) sebesar
$0,782>0,5$ dan $T$-statistic sebesar 13,758 $>\mathrm{T}$ tabel sebesar 1,96. Hal ini menunjukkan bukti bahwa indikator kecerdasan logika matematika sebagai instrument variabel kecerdasan majemuk dengan taraf signifikan pada 0,05. Indikator X23 (kecerdasan visual-spasial) sebesar 0,773>0,5 dan T-statistic sebesar $17,589>\mathrm{T}$ tabel sebesar 1,96. Hal ini menunjukkan bukti bahwa indikator kecerdasan visual-spasial sebagai instrument variabel kecerdasan majemuk dengan taraf signifikan pada 0,05. Indikator X24 (kecerdasan bodily kinestetik) sebesar $0,809>0,5$ dan $T$ statistic sebesar 15,755 > T tabel sebesar 1,96. Hal ini menunjukkan bukti bahwa indikator bodily kinestetik sebagai instrument variabel kecerdasan majemuk dengan taraf signifikan pada 0,05. Indikator X25 (kecerdasan musikal) sebesar 0,663 > 0,5 dan T-statistic sebesar $6,711>\mathrm{T}$ tabel sebesar 1,96. Hal ini menunjukkan bukti bahwa indikator kecerdasan musikal sebagai instrument variabel kecerdasan majemuk dengan taraf signifikan pada 0,05 . Indikator X26 (kecerdasan interpersonal) sebesar 0,687 > 0,5 dan T-statistic sebesar 7,758 > T tabel sebesar 1,96. Hal ini menunjukkan bukti bahwa indikator kecerdasan interpersonal sebagai instrument variabel kecerdasan majemuk dengan taraf signifikan pada 0,05. Indikator X27 (kecerdasan intrapersonal) sebesar $0,552>0,5$ dan $T$ statistic sebesar 5,675> T tabel sebesar 1,96. Hal ini menunjukkan bukti bahwa indikator kecerdasan intrapersonal sebagai instrument variabel kecerdasan majemuk dengan taraf signifikan pada 0,05. Indikator X28 (kecerdasan naturalis) sebesar 0,537 >0,5 dan T-statistic sebesar $5,511>\mathrm{T}$ tabel sebesar 1,96. Hal ini menunjukkan bukti bahwa indikator kecerdasan naturalis sebagai instrument variabel kecerdasan majemuk dengan taraf 
signifikan pada 0,05 .

Variabel motivasi berprestasi mahasiswa pada Tabel 4.1 menunjukkan bahwa indikator X31 (memiliki preferensi untuk mengerjakan tugas-tugas) sebesar 0,770 > 0,5 dan T-statistic sebesar 9,890 > T tabel sebesar 1,96. Hal ini menunjukkan bukti bahwa indikator memiliki preferensi untuk mengerjakan tugas-tugas sebagai instrument variabel motivasi berprestasi mahasiswa dengan taraf signifikan pada 0,05. Variabel motivasi berprestasi mahasiswa pada Tabel 4.14 menunjukkan bahwa indikator X32 (menyukai situasisituasi di mana kinerja mereka timbul karena upaya upaya sendiri) sebesar 0,897 > 0,5 dan T-statistic sebesar 39,084 > T tabel sebesar 1,96. Hal ini menunjukkan bukti bahwa indikator menyukai situasisituasi di mana kinerja mereka timbul karena upaya upaya sendiri sebagai instrument variabel motivasi berprestasi mahasiswa dengan taraf signifikan pada 0,05 . Indikator X33 (menyukai umpan balik tentang tugas yang diberikan) sebesar 0,812>0,5 dan T-statistic sebesar $10,873>\mathrm{T}$ tabel sebesar 1,96. Hal ini menunjukkan bukti bahwa indikator menyukai umpan balik tentang tugas yang diberikan sebagai instrument variabel motivasi berprestasi mahasiswa dengan taraf signifikan pada 0,05 .

\subsubsection{Pengujian Inner Model. ${ }^{78}$}

Hipotesis statistik untuk inner model yakni variabel laten eksogen terhadap endogen. Berdasarkan pada Tabel 4.2, pengaruh gaya belajar terhadap kecerdasan majemuk dengan koefisien gamma sebesar 0,556 dan T-statistic sebesar 8,983 > T tabel sebesar 1,96 pada gaya belajar terhadap kecerdasan majemuk, berarti terdapat pengaruh signifikan gaya belajar terhadap kecerdasan majemuk dengan level signifikan 0,01 .

Tabel .4.2 Result for Inner Weight pada Output PLS

\begin{tabular}{|c|c|c|c|c|}
\hline & $\begin{array}{l}\text { origin } \\
\text { al } \\
\text { sampl } \\
\text { e } \\
\text { estima } \\
\text { te }\end{array}$ & $\begin{array}{c}\text { mean of } \\
\text { subsamp } \\
\text { les }\end{array}$ & $\begin{array}{c}\text { Standa } \\
\text { rd } \\
\text { deviati } \\
\text { on }\end{array}$ & $\begin{array}{c}\text { T- } \\
\text { Statist } \\
\text { ic }\end{array}$ \\
\hline $\begin{array}{l}\text { G aya } \\
\text { Belajar } \\
\rightarrow \\
\text { Kecerdas } \\
\text { an } \\
\text { majemuk }\end{array}$ & 0.556 & 0.586 & 0.062 & 8.983 \\
\hline $\begin{array}{l}\text { G. } \\
\text { Belajar } \\
\rightarrow \\
\text { Motivasi } \\
\text { berpresta } \\
\text { si }\end{array}$ & 0.269 & 0.265 & 0.121 & 2.215 \\
\hline $\begin{array}{l}\text { Kecerdas } \\
\text { an } \\
\text { majemuk } \\
\rightarrow \\
\text { Motivasi } \\
\text { berpresta } \\
\text { si }\end{array}$ & 0.510 & 0.516 & 0.121 & 4.220 \\
\hline
\end{tabular}

Sumber : Hasil PLS dari pengolahan data primer (2017)

Berdasarkan pada Tabel 4.2, pengaruh gaya belajar terhadap motivasi berprestasi mahasiswa dengan koefisien gamma sebesar 0,269 dan T-statistic sebesar 2,215 > T tabel sebesar 1,96 pada gaya belajar terhadap motivasi berprestasi mahasiswa, berarti terdapat pengaruh signifikan gaya belajar terhadap motivasi berprestasi mahasiswa dengan level signifikan 0,01 .

Berdasarkan pada Tabel 4.2, pengaruh kecerdasan majemuk, terhadap motivasi berprestasi dengan koefisien 
gamma sebesar 0.510 dan T-statistic sebesar $4.220>\mathrm{T}$ tabel sebesar 1,96 pada kecerdasan majemuk terhadap motivasi berprestasi mahasiswa, berarti terdapat pengaruh signifikan kecerdasan majemuk terhadap motivasi berprestasi mahasiswa kecerdasan majemuk dengan level signifikan 0,01 .

\section{Kesimpulan Dan Saran}

\subsection{Kesimpulan}

Berdasarkan hasil analisis data dan pembahasan sebelumnya serta berdasarkan evaluasi Goodness of Fit Model Partial Least Square (PLS) serta pengujian hipotesis, maka temuan penelitian dapat disimpulkan sebagai berikut :

1. Pengaruh gaya belajar terhadap kecerdasan majemuk: terdapat pengaruh signifikan gaya belajar terhadap kecerdasan majemuk dengan level signifikan 0,01. Gaya belajar mahasiswa memberikan pengaruh langsung terhadap kecerdasan majemuk pada mahasiswa peserta mata kuliah pendidikan agama Kristen.

2. Pengaruh gaya belajar terhadap motivasi berprestasi mahasiswa: terdapat pengaruh signifikan gaya belajar terhadap motivasi berprestasi mahasiswa dengan level signifikan 0,01. Gaya belajar mahasiswa memberikan pengaruh langsung terhadap motivasi berprestasi mahasiswa peserta mata kuliah pendidikan mata kuliah agama Kristen.

3. Pengaruh kecerdasan majemuk, terhadap motivasi berprestasi: terdapat pengaruh signifikan kecerdasan majemuk terhadap motivasi berprestasi mahasiswa kecerdasan majemuk dengan level signifikan 0,01. Peningkatan kecerdasan majemuk berpengaruh terhadap motivasi berprestasi mahasiswa peserta mata kuliah pendidikan mata kuliah agama Kristen.

\subsection{Saran}

Berdasarkan hasil penelitian, peneliti memberikan beberapa hal yang perlu disempurnakan baik oleh praktisi maupun teoritis, antara lain :

1. Mahasiswa peserta mata kuliah PAK angkatan 2016/2017 memiliki gaya belajar, kecerdasan majemuk dan motivasi berprestasi yang baik, untuk itu perlu diteliti lanjutan tentang dampak dalam capain prestasi skala Kopertis 3, Nasional maupun Internasional.

2. Perlu dilakukan penelitian lanjutan metode mengajar berdasarkan gaya belajar dan kecerdasan majemuk untuk menumbuhkan motivasi berprestasi mahasiswa.

3.

\section{Daftar Pustaka}

Alkitab, LAI, 2010

Agus Efendi. Revolusi Kecerdasan Abad 21. Bandung: Alfabeta, 2005.

Bobby DePorter \& Mike Hernacki. Quantum Learning. Bandung: Mizan, 1999.

Calvin, Yohanes. Instutio. Pengajaran Agama Kristen. Jakarta: BPK Gunung Mulia, 2013.

Eveline Siregar, Hartini Nara. Teori Belajar dan Pembelajaran. Bogor: Ghalia Indonesia, 2010.

Ghozali, Imam. Structural Equation Modelling Metode Alternatif dengan Partial Least Square. Semarang: Badan Penerbit Universitas Diponegoro, 2011.

Groome H. Thomas. Christian Religius Education. Jakarta: BPK Gunung Mulia. 2011.

Homrigausen E.G dan I.H. Enklaar. Pendidikan Agama Kristen. Jakarta: BPK Gunung Mulia, 2015. 
Khoe Yao Tung. Pembelajaran dan Perkembangan Belajar. Jakarta: Indeks, 2005.

Luthans, Fred, :" Perilaku Organisasi", Edisi Sepuluh, Yogyakarta: Andi, 2016.

Martinis Yamin. Strategi Pembelajaran Berbasis Kompetensi. Jakarta: Gaung Persada Press, 2004.

Nazir, M., Metode Penelitian. Jakarta: Ghalia Indonesia, 2005.

Ratna Wilis Dahar. Teori-teori Belajar dan Pembelajaran. Jakarta: Erlangga, 2011.

Robert R. Boehlke. Sejarah Perkembangan dan Praktek PAK: dari Yohanes Amos Comenius hingga Perkembangan PAK di Indonesia. (Jakarta: BPK-Gunung Mulia, 2003.

Robbins, Stephen P, "Perilaku Organisasi, Edisi kesepuluh, Jakarta: PT Indeks, 2007.

Sardiman. Interaksi \& Motivasi Belajar Mengajar. Jakarta: Rajawali Press, 2016.

Singarimbun, M \& Effendi, S. Metode Penelitian Survey. Jakarta: LP3ES. Volume 19, No.3, Oktober, 2011.

Suarni Ni Ketut. Metode Pengembangan Intelektual. (Yogyakarta: Graha Ilmu, 2014

Uno, Hamzah B. Teori Motivasi \& Pengukurannya Analisis di Bidang Pendidikan. Jakarta: Bumi Aksara, 2007.

\section{Jurnal:}

Fred \& Melodt (2016). Applying Multiple Intelligences in the Classroom: A Fresh Look at Teaching Writing. INTERNATIONAL JOURNAL OF SCHOLARLY ACADEMIC INTELLECTUAL DIVERSITY VOLUME 16, NUMBER 1, 2014, 113.

http://www.nationalforum.com/Electronic $\% 20$ Journal\%20Volumes/Lunenburg,\%20Fr ed $\% 20 \mathrm{C} \% 20$ Applying\% $\%$ Multiple $\% 2$ 0Intelligences\%20IJSAID\%20V16\%20
N1\%202014.pdf. Diunduh 2 Februari 2017.

Jeanete dan Neleke (2016), IDENTIFIKASI GAYA BELAJAR MAHASISWA. Jurnal Psikologi Undip Vol.15 No.1 April 2016, 56-63. https://ejournal.undip.ac.id/index.php/p sikologi/article/viewFile/12992/9731. Diunduh 12 April 2017.

Omoniyi \& Olurinola. EDUCATIONAL MULTIMEDIA AND LEARNING STYLE PREFERENCES. British Journal of Education. Vol.3, No.12, pp.29-42, December 2015, http://www.eajournals.org/wpcontent/uploads/EducationalMultimedia-and-Learning-StylePreferences.pdf diunduh 3 Fberuari 2017

Petros and Todd D. Fantz . A Comparative Analysis of Preferred Learning and Teaching Styles for Engineering, Industrial, and Technology Education Students and Faculty. Journal of Technology Educatio. Vol. 23 No. 2, Spring 2012, 61-69. https://scholar.lib.vt.edu/ejournals/JTE/ v23n2/pdf/katsioloudis1.pdf. Diunduh 5 Maret 2017.

\section{Buku/Dokumen}

Dokumen Peraturan Pemerintah Republik Indonesia Nomor 55 Tahun 2007 Tentang Pendidikan Agama Dan Pendidikan Keagamaan.

Renstra UKI 2015-2019

Wahyu A. Rini dkk, Bahan Ajar Mata kuliah Etika UKI, 2014. 